\title{
Abolishing Ius Sanguinis Citizenship: A Proposal Too Restrained and Too Radical
}

\author{
Kristin Collins
}

Costica Dumbrava maintains that ius sanguinis citizenship is a historically tainted, outmoded, and unnecessary means of designating political membership. He argues that it is time to abandon it. His proposal is bold, and it has significant implications for an array of policies and practices. The parentchild relationship not only serves as a basis for citizenship transmission; it also entitles individuals to immigration preferences, and - in some countries - it facilitates automatic or 'derivative' naturalisation of the children of naturalised parents. In many countries that recognise ius soli citizenship, the parent-child relationship serves as an added requirement: one must be born in the sovereign territory and be the child of a citizen or a long-term legal resident. Dumbrava limits his challenge to ius sanguinis citizenship per se, and even suggests that family-based migration rights could be used to minimise the disruptive effect of abolishing citizenship-by-descent. But his core complaints about ius sanguinis citizenship - the mismatch of biological parentage and political affinity, the difficulties of determining legal parentage can be, and have been, levied against these various family-based preferences and statuses, which are likely found in every nation's nationality laws. It is therefore important to consider his proposal in light of the role that the parent-child relationship plays in the regulation of migration, naturalisation, and citizenship more generally. With this broader context in mind, I concur with Rainer Bauböck and Jannis Panagiotidis that Dumbrava's proposal rests on an under-informed assessment of the historical record. I also argue that that, as a remedy for the problems that he has identified, Dumbrava's proposal is at once too restrained and too radical.

\section{The complex history of ius sanguinis citizenship}

Dumbrava first argues that ius sanguinis citizenship should be abolished because, historically, it has been associated with ethno-nationalist conceptions of citizenship. I appreciate Panagiotidis' insistence that 'the problem is not with ius sanguinis itself, but with the respective contexts in which it is embedded'. Panagiotidis also reminds us that ius sanguinis citizenship has 
sometimes functioned to create political communities that draw from different ethnic and religious groups, as in the case of German Jews whose membership in the German polity was secured by the country's ius sanguinis laws prior to the Nazi era. I want to elaborate and underscore the importance of this point with an additional example from United States history: During seventy years of Chinese exclusionary laws, ius sanguinis citizenship provided one of the very few routes to entry, and to American citizenship, for ethnic Chinese individuals born outside the U.S. For precisely that reason, exclusionists sought to limit or repeal the ius sanguinis statute, which recognised the foreign-born children of American fathers as citizens. ${ }^{1}$ If one expands the historical frame to include parent-child immigration preferences and derivative naturalisation, the story becomes even more complex. By 1965, the race-based exclusions and national-origins quotas had been abolished, and previously excluded Asian families began immigrating to the U.S. in unprecedented numbers. ${ }^{2}$ They were able to do so by relying on the generous family-based preferences in American immigration and nationality laws, which facilitated entry, settlement, and - especially significant to this discussion - derivative naturalisation for children. ${ }^{3}$

Even a cursory review of the historical record thus counsels a cautionary assessment of the contention that ius sanguinis citizenship's tainted past justifies its abolition. First, calls to end ius sanguinis citizenship have their own ugly history. Second, although one cannot gainsay that, in certain circumstances, ius sanguinis citizenship has been used to maintain ethnic homogeneity, the notion that parents and children do and should share the same political affiliation has also facilitated racial, ethnic, and religious diversification of some political communities. Rather than abolish ius sanguinis citizenship wholesale, we should be alert to the ways that it can operate as a tool

For a discussion of these laws and efforts to restrict the recognition of ethnic Chinese individuals under the ius sanguinis citizenship statute, see Collins, K.A. (2014), 'Illegitimate Borders: Jus Sanguinis Citizenship and the Legal Construction of Family, Race, and Nation', Yale Law Journal 123 (7) 2134 2235 (at 2170-2182). Starting in 1934, the ius sanguinis statute also allowed American mothers to transmit citizenship to their foreign-born children. See id. at 2157.

2 See Reimers, D. (1983), 'An Unintended Reform: The 1965 Immigration Act and Third World Immigration to the United States', Journal of American Ethnic History 9 (3): 23-24; Ong Hing, B. (1999), Making and Remaking Asian America Through Immigration Policy, 1850-1900. Stanford: SUP, 81-120.

3 See, for example, Immigration and Nationality Act of 1952, 66 Stat. 163, 245, $\S 323$. 
of ethnic exclusion and degradation in particular socio-legal contexts, and work to minimise those effects. ${ }^{4}$

\section{A proposal too restrained and too radical}

To be fair, Dumbrava does not extend his proposal to migration and naturalisation policies that enlist the parent-child relationship; indeed, he would preserve such migration policies. He speaks only of traditional ius sanguinis citizenship, and argues that it often fails to map on to the reality of modern family formation, making it inadequate to 'deal with contemporary issues such as advances in assisted reproduction technologies' (ART), same-sex coupling and marriage, and the steady rise of nonmarital procreation. The problems Dumbrava identifies in this regard are important and difficult. But as a remedy for these problems, abolishing parent-child citizenship transmission is simultaneously too restrained and too radical. It is too restrained because, after abandoning ius sanguinis citizenship we would still be confronted with the difficulty of determining which parent-child relationships should count for purposes of regulating migration, derivative naturalisation, and (in many countries) ius soli birthright citizenship. Moreover, in all of these contexts, the 'fundamental normative questions about who should be a citizen in a political community' - and about the role that the parent-child relationship should play in that determination - would persist.

At the same time, Dumbrava's proposal is too radical. He argues that ius sanguinis citizenship is not necessary to protect children from statelessness and 'adds little to the legal and normative character of the parent-child relationship'. On this point I agree entirely with Bauböck and Scott Titshaw that Dumbrava underestimates the disruptive potential of his proposal. If all countries recognised unrestricted ius soli citizenship, Dumbrava's assertion that ius sanguinis citizenship is unnecessary to prevent statelessness would be basically correct. But, in fact, very few ius soli countries go that far. Instead, as noted, they use ius sanguinis concepts to restrict the operation of ius soli birthright citizenship, thus leaving some children at a risk of statelessness if traditional ius sanguinis citizenship were abolished. And it is not just formal statelessness that would increase in a world without ius sanguinis citizenship. Children whose citizenship does not align with that of their

\footnotetext{
A particularly notable example of how ius sanguinis principles can operate as tools of ethno-racial exclusion is the 2013 ruling of the Constitutional Tribunal of the Dominican Republic, TC/0168/13, which effectively expatriated ethnic-Haitian individuals born and residing in the D.R., leaving hundreds of thousands of people stateless.
} 
parents can find themselves divided by nationality from the individuals who are charged, ethically and legally, with their care. As Bauböck and Titshaw observe, in an era of voluntary and compelled migration, ius sanguinis is the most effective method of protecting against such destabilising and precarious circumstances.

\section{How to modernise?}

I agree with Titshaw and Bauböck that the modernisation of ius sanguinis citizenship, rather than its complete repudiation, offers a better way to address the problems Dumbrava identifies. The difficult question is how? I am hesitant to embrace Titshaw's proposed method of modernisation, and I offer a friendly but important amendment to Bauböck's proposal.

Titshaw argues that the officials who administer citizenship law should adhere to the parentage determinations made by officials who generally administer family law. In the U.S., these are state-level family law judges applying state law. But domestic family law, in the U.S. and elsewhere, does not necessarily generate ideal or even tolerable outcomes on questions of citizenship. Titshaw holds up a particularly poorly drawn U.S. federal policy that regulates ius sanguinis citizenship as it applies to foreign-born children conceived using ART, but there are many examples of how the use of state family law to regulate citizenship transmission has generated equally objectionable outcomes. ${ }^{5}$

Alternatively, Bauböck would have us adopt a 'ius filiationis' standard that recognises the 'social parent' or the 'primary caregiver' as the parent for purposes of ius sanguinis citizenship. He urges that this would help remedy the 'mismatch between biologically determined citizenship and parental care arrangements that would also open the door to abusive claims'. He is correct. My concern, however, is that his emphasis on 'social parenting' and 'primary caregiving' is insufficient and has its own perils. First, it could

\footnotetext{
For example, in 1940 the federal ius sanguinis citizenship statute was amended to include the nonmarital children of U.S. citizen fathers under certain circumstances, such as when the father had 'legitimated' the child. Federal officials turned to the law of the father's domiciliary state to determine whether legitimation had, in fact, occurred. In the 1940s and 50s, marriage to the child's mother was a very common mode of legitimation, but federal officials making citizenship determinations would not recognise an interracial marriage as the basis of a child's citizenship claim if the father's home state banned such marriages - and many did. See Collins, 'Illegitimate Borders', above n. 2, at 2210 .
} 
increase the likelihood of abusive denials of citizenship by officials who, at least in the U.S., are often all too eager to find reasons to reject claims to citizenship. ${ }^{6}$ In the case of nonmarital children - who make up a far greater portion of the global population than children conceived through ART - the restriction of parent-child citizenship transmission to 'primary caregivers' could lead to circumspect treatment, or outright rejection, of the father-child relationship as a basis for citizenship transmission. Indeed, the primary caregiver standard could stymie the caregiving efforts of unmarried fathers who are divided by nationality from their children, and hence may never be able to establish themselves as the 'primary caregiver'. The emphasis on caregiving as a prerequisite could also aid unmarried fathers who prefer to avoid parental responsibility by distancing themselves geographically from their children. The result: a ius sanguinis citizenship regime that would buttress gender inequality by undermining men's parental rights and helping them to avoid their parental responsibilities. ${ }^{7}$ Moreover, and regardless of one's view of the equities as between parents, it is ultimately the nonmarital child's citizenship and migration rights that could be destabilised, depending on how officials understood the concept of 'social parent'. Dumbrava recognises the inequities associated with 'the differential treatment of children born within and out of wedlock with respect to access to citizenship', but his solution - to abolish parent-child citizenship transmission altogether - would give cold comfort to nonmarital children and marital children alike.

This is not an endorsement for a purely genetic model of citizenship transmission. Despite the references to 'blood', ius sanguinis citizenship has never rested on purely biological conceptions of citizenship. Traditionally, marriage was fundamental to the ability of fathers to secure citizenship for their children, and - at least in the development of U.S. law - the presumption that the mother is the sole caregiver of the nonmarital child led to the recognition of the mother-child relationship as a source of citizenship for foreign-born nonmarital children. ${ }^{8}$ Rather, I suggest that - unless and until we move beyond citizenship as the enforcement mechanism for basic human rights, and beyond the family as a foundational source of material and psychological support for children, we cannot overstate the importance of

6 See, for example, Saldana Iracheta v. Holder, 730 F.3d 419 (5th Cir. 2013).

7 I develop this argument in: Collins, K.A. (2000), 'When Fathers' Rights Were Mothers' Duties: The Failure of Equal Protection in Miller v. Albright', Yale Law Journal (109) 1669-1708 (1699-1705), and in 'Illegitimate Borders', above n. 2, at 2230-34.

8 See Collins, 'Illegitimate Borders', above n. 2, at 2199-2205. 
the generous recognition of the parent-child relationship for citizenship transmission. The modernisation of ius sanguinis citizenship should thus include the recognition of 'social parents' and parents with 'custodial rights' - as Bauböck rightly asserts - and also recognition of all who can be held legally responsible for a child's care or support. Dumbrava may be unhappy that the whims of parents, people's reproductive choices, and factors beyond the control of the individual would continue to determine membership in a political community. But it is precisely because citizenship designations rest on factors such as these that I wholly agree with his admonition that we channel our efforts 'towards consolidating democratic institution and promoting citizenship attitudes and skills among all those who find themselves, by whatever ways and for whatever reason, in our political community'.

Open Access This chapter is licensed under the terms of the Creative Commons Attribution 4.0 International License (http://creativecommons.org/licenses/by/4.0/), which permits use, sharing, adaptation, distribution and reproduction in any medium or format, as long as you give appropriate credit to the original author(s) and the source, provide a link to the Creative Commons license and indicate if changes were made.

The images or other third party material in this chapter are included in the chapter's Creative Commons license, unless indicated otherwise in a credit line to the material. If material is not included in the chapter's Creative Commons license and your intended use is not permitted by statutory regulation or exceeds the permitted use, you will need to obtain permission directly from the copyright holder.

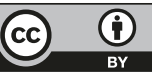

